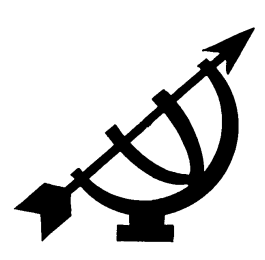

\title{
Telling women to be like men? Some theoretical aspects regarding the interpretation of the Bible on gender issues ${ }^{1}$
}

\author{
Gerrie Snyman
}

Department of Old Testament

Unisa

PRETORIA

E-mail: snymagf@unisa.ac.za

\section{Abstract}

Telling women to be like men? Some theoretical aspects regarding the interpretation of the Bible on gender issues

The RCSA is in desperate need of a new way of approaching the Bible. The hermeneutical principles that gave birth to a theological legitimation of apartheid are still active in the theological legitimation of a patriarchal order in the RCSA (Gereformeerde Kerke in Suid-Afrika). It is as if the RCSA suffers from a theological schizophrenia which bars a critical approach from taking root. The article explores some hermeneutical impediments within the RCSA, illustrated by the 2000 Synod and a declaration published for the advent of Reformation Day in October 2000. Those impediments can be traced back to a seminal article of the 1980s, written by J.C. Coetzee, B.J. de Klerk and L. Floor ("Die hermeneuse van die Skrif met die oog op hedendaagse kerklik-etiese vraagstukke"), and to the influence of Afrikaner civil religion in the reading of the Bible. In the light of these three aspects, the article surveys the problem of imitating the text in terms of its values or characters, since the discussion of the role of women in the church is based on what is said about women in the Bible as a male text. The article concludes with a tentative proposal for an ethics of reading, with regard to the theoretical aspects when discussing gender issues in the Bible.

1 This article is a revised version of a paper delivered at a conference held at the PU for CHE during 2-4 May 2001 on the theme "Women in church and society". It forms part of a research project undertaken by the Faculty of Theology (PU for CHE) that focuses on Reformed Theology and the development of South African society. The paper was delivered as part of the project that concerns the socio-historic context of the Bible and its implications for the development of South African society. 
1. A rhetoric of power

\subsection{A theological schizophrenia}

My basic contention is that South African reformed hermeneutics in general, and the RCSA in particular, is in desperate need of a new way of approaching the Bible (cf. Snyman, 1997a and 1997b). It is not a new claim, nor is a new solution suggested. In 1984 the late Willem Vorster (1984:205) contested the claims of different people to present a "biblical view" on our society. One group argued that apartheid was biblical, and another group argued that the liberation struggle was biblical. Both claimed to follow the biblical way. Vorster (1984:205) argued that their readings should be regarded as products of a contextualised theology based on social interaction, and only legitimised as a religious convention by an appeal to Scripture. In the end one has two groups of people operating with the same view of Scripture but with different readings, because the political grid through which the Bible is read, had changed (Vorster, 1984:210).

In both instances the borderlines between biblical message and ideology become blurred. In both cases the Bible is used as a proof-text that affords authority to a particular point of view. Vorster's point is that people with different values will have different reading results. The reading that wins is the reading that is supported by the political power of the day. When power is involved it is inevitable that the religiousecclesiastical institutionalisation of values will lead to unrest and upheaval while the political, economic, educational and social trends evolve in society. This is illustrated by the current debate regarding the previous theological justification of apartheid. What was then theologically justified has now become heretical. The same occurs with the position of women in society and within the churches. A few years ago the role of women in the churches was ordered along the lines of a patriarchal order. With the entrenchment of human rights in the South African constitution in 1994, patriarchy has come increasingly under fire, so that the issue of equal rights brings the matter of women in the ministry to the front door of the RCSA.

My fear is that, as with apartheid, a basic schizophrenia latent in the reformed tradition (as interpreted by Kuyper and Bavinck) may rear its head when the RCSA decides about opening up former male enclaves. Vroom (1993a:358) argues that although Kuyper acknowledged a hermeneutical space, by allowing the human factor to play a significant role, the moment the authority of Scripture was mentioned, that space disappeared. The Bible had absolute authority and full certainty. The same 
happens with Bavinck, says Vroom (1993a:363) in comparing his hermeneutics with a time bomb:

He combines two opposing lines: that of absolute authority and the broad, unshakeable certainty of faith on the one hand and openness in the search for the true meaning of texts and their correct application in modern life on the other.

According to Vroom, when Bavinck declared revelation as a form of history, he meant that not everything written in the Bible has normative authority for faith or life. However, Bavinck does not follow through with this idea, because he refuses to allow readers to decide what is authoritative or not. He turns to Scriptural authority and turns it into divine authority. The Bible becomes God.

The South African reformed tradition has not yet found a solution to the role played by the human factor in the production and reading processes of the Bible. It is as if any focus on the human element constitutes a destruction of scriptural authority (cf. Vroom, 1993b:94). Attention to the human element indeed renders existing rules of interpretation problematical (though not necessarily evil). The recognition of the human element leads to an historical consciousness, because the contexts in which meaning is produced (social, political, cultural or economical) become important. But this recognition comes at a price. The Bible is no longer interpreted as if the books constitute a set of principles of universal application and validity. The Bible is still read but the universality of the principles inferred from it has become questionable. A changed system of values does not render the Bible obsolete, but only questions the validity of old traditional interpretations in the light of the results of ongoing theological research. Bible interpretation is no longer self-evident.

\subsection{Critical theology?}

An historical awareness opens the way for an evaluation of values situated in different periods and cultures. It is a critical enterprise, and in the form of a theology that is more critical it should not be regarded as a guarantee against Bible readings that lead to human rights abuses (cf. Van Wyk, 1997:10). In fact, the argument is not about guarantees, but about ways to read the Bible creatively without falling into the same traps into which an uncritical theology fell in legitimising apartheid.

In their critique of apartheid theology, the Presbyterian Churches of Southern Africa (cf. Bax, s.a.:28) claimed that the theology of apartheid not only perverted the meaning of the Bible, but that it also contradicted the Reformers' interpretation. In their view, this perversion of Calvinism 
found its roots in Jean Jacques Rousseau's influence on German Romanticism which, in turn, affected Kuyper: "Kuyper's theology of culture and volk opened the way for Romantic nationalism in its German form, which was becoming fused with racism (and anti-Semitism), to penetrate the thinking of Afrikaner intellectuals" (Bax, s.a.:31; cf. Kinghorn, 1986:53-68).

The result was a double vision in that knowledge of the revealed will of God was directly derived from the order of creation as well as from texts in Scripture, while ignoring the central redemptive message of the life and work of Christ (Bax, s.a.:40). This double vision or schizophrenia is present in the thinking of the RCSA when members link the position of women in the church to the order of creation (cf. GKSA, 1988:510). Somehow, one would like to argue that the redemptive message of Christ has freed women from this oppressive order of creation, but Paul seems to perpetuate it, as Castelli (1991) has shown. In the New Testament, patriarchy remains a God-given order (GKSA, 1988:512). Is the Early Church perceived as denying Christ's liberative actions? The New Testament may provide ammunition against the separation of people (Jews versus Gentiles), but it does not do the same for women, because it was written within a patriarchal social order which, today, due to a change in values, is perceived as quite oppressive. Is it possible to find evidence in the New Testament for opening up the ministry to women if these texts originated in an environment that is hostile to any power given to women? The only way would be to question the social order in which these texts were once produced. But those questions need hermeneutical space. The challenge for the RCSA is to find the courage to take Kuyper's "hermeneutical space" seriously, or to follow up on Bavinck's suggested openness (if one follows Vroom's reading of them).2

As a member of the RCSA, one has to deal with the following dilemma. The moment one distances oneself from a theological justification of apartheid (accepting its inherent immorality), an act of "Bible criticism" is committed. A principle found in the Bible is rejected. That principle is one of selection and separation according to which ancient Israel, as an

2 Currently, the idea of "critical theology" is anathema to the South African reformed tradition. The reformed tradition never officially espoused a critical line of thought. This is also true for the Hervormde Kerk van Afrika, that uses the term "critical" only in so far as it wants to create a distance between their viewpoints over against those of the RCSA. The current debate within the Hervormde Kerk shows that any reference to criticism regarding the Bible or theology never had popular support (cf. Loader, 1996). In any case, those who had the power in the past, never explained the consequences of a critical theology (cf. Loader, 1979). 
elected people of God, set themselves apart from the other inhabitants of Palestine. In the narrative world of the Bible, there were reasons for them to do so. The moment one decides that those reasons are no longer valid, a certain set of principles (separatist values) in the biblical text is rejected. This is Bible criticism, even when a principle from the New Testament is used, as is the case within the anti-apartheid lobby (cf. Bax, s.a.:23-26). Unfortunately, this is impossible when one deals with women, as the New Testament texts are as biased against women as the Old Testament texts are.

To argue that the problem lies with the faulty disposition of the reader, explained as "sin", is to lay the burden of proof on the reader in order to render the biblical text blameless, irreproachable, or absolutely authoritative. The more a reader is portrayed as an illogical, baseless being, the more absolute, objective, foundational and set apart from any human contamination the biblical text becomes. It is as if the inherent falseness of the reader is complemented by the truthfulness of the biblical text. The end result is that reader responsibility is evaded, in that the "erroneous" reader hides behind a divine text.

In these arguments the process of reading is never put on the table. Nor those morals and values that are strange to present-day society. What does one do with what Michael Prior (1997:292) calls, in a study on the Bible and colonialism, "menacing ideologies and racist, xenophobic and militaristic tendencies", which are dangerous if read without any respect for the literary genre and the world of text production? Can one really say that it is the readers' fault if they follow reprehensible morals in the Bible stories because they believe them to be God's will?

The mode of reading in the RCSA is one where the text is supposed to draw readers out of themselves, internalising the values embedded in the text, because the text provides readers with God's revelation of his will for their lives on earth. But does it mean readers should be blind to the rhetoric, the ideology, and the power of the text? To repeat the questions the late Robert Carroll (1993:87) once asked: "Is literature always innocent? Must the reader always be naive, even if that naiveté approaches the Ricoeurian level of a 'second naiveté'?"

\subsection{Dialogicity}

My contention is that the Bible, to a large extent, excludes women from any public participation in religious affairs. The exclusion is based on the patriarchal nature of the society in which the biblical texts were produced, the Hebrew Bible as well as the early Christian texts. It is inappropriate, or morally wrong, to use these texts to exclude women from the ministry. 
Our society has changed. If women participate in economic life, earning a salary as well as bearing and rearing children, what moral right do men have to exclude them from public office in the realm of religion?

Such a point of view may be unnerving and unsettling. However, these questions can be asked from the intellectual viewpoint of a critical scholar (cf. Snyman, 1999a:157 f.f.). The role of an intellectual is not that of a caretaker of religion, but that of a critic of religious practices and beliefs. With religion being such a touchy subject, no audience will feel satisfied, but as Edward Said argues in his book, Representations of an Intellectual (1994:9), the whole point is to be embarrassing, contrary, even unpleasant.

Central to the activity of an intellectual is critical engagement with ideas. The act requires space and independence and it extends beyond those whose task it is to provide the dominant class with forms of moral, ideological and intellectual leadership (cf. Lansink, 2000:47). Intellectual engagement is no smooth talking (cf. Amador, 1999:303), but a deliberate attempt at unseating the monological voice of the public transcript (cf. Snyman, 1998) that keeps out from public space the female voice, which is still subordinated to the male voice.

In terms of a typical Bakhtinian dialogicity (Bakhtin, 1984) the issue of women in the church is approached from a rhetoric of power, inquiring into the argumentative and persuasive effects of a particular approach. The concern is not the question of meaning so much as it is uncovering the consequences of a specific interpretation. It will be disruptive to the power paradigms currently at work. No one likes to see their own vulnerabilities, limitations or inconsistencies. For example, this author's would be the lack of a fully worked-out alternative. His thinking is preliminary, contextual, devoid of any really universal validity. It is not a clear-cut doctrine, but, in the spirit of dialogicity, is open for discussion.

The article starts with a description of the nature of the uncritical attitude in which the current discussion of the role of women in the church is taking place, namely male officials of the church "taking care" of religion within the RCSA. The article proceeds to discuss the framework within which theology is practised. That framework is found in the commonsense realism of the early Afrikaner civil religion and the latent objectivist hermeneutics behind the locus classicus of the current hermeneutics in the RCSA, namely a seminal article in 1980 written by Prof. J.C. Coetzee, Dr. B.J. de Klerk and Prof. L. Floor. An objectivist reading of a benign text invites imitation. Subsequently, the article explores how the change in values or norms renders imitation problematical. Finally, the 
article concludes with a tentative proposition regarding the theoretical aspects of a discussion of gender issues in the Bible.

\section{The uncritical attitude within the current debate}

\subsection{Men "taking care" of religion}

The 2000 Synod, constituted by male dominees and elders, reaffirmed the church's official position that women cannot become ministers, deacons or elders (GKSA, 2000:385; cf. GKSA, 1988:507-523; GKSA, 1994:467-488). At this particular synod, a dominee had a specific problem. He was working in a community trying to resuscitate a congregation that had fallen apart. His problem was that the would-be congregants were only women. His question was whether he could establish a congregation. The advice given was that no congregation could be established as there were no competent men around (GKSA, 2000:385). From the brief report in the acts of the Synod, one realises that there is no critical engagement with the decision's effect and even that the advice reminds one of the Roman Catholic tradition which says that there can be no church when there is no priest. ${ }^{3}$

A similar lack of critical engagement with one's own tradition can be perceived in the declaration (cf. De Klerk et al., 2000) published by eleven theological scholars at the Faculty of Theology at the PU for CHE. It was the day prior to the commemoration of the Reformation and just after a serious debate about the historicity of Jesus in the newspaper, Beeld. The statement created a particular rhetorical situation. Its authors went by the label "Theologians of the Theological School in Potchefstroom" and not the appellation "Faculty of Theology at PU for CHE" which one would have expected from an academic institution housing theological scholars. The use of the former appelation is common in circles of the RCSA. Its use allowed the authors to operate in a pastoral way, like dominees, soothing the fears of church members. In this way they were not obliged to provide academic (rational?) arguments. The statement functions on an ideological level, stating the parameters of thinking in the RCSA.

With this statement the frail and insecure were assured that the doctrines they believed were still intact. The testimony was a declaration of truth

3 This little incident indicates the barriers one has to cross within the RCSA to obtain gender equality. In the reports about this incident in Beeld (cf. Jackson, 2000a; 2000b; 2000c and 2000d; cf. also Snyman, 2001) one can observe an interaction of social dynamics and interpretive theory leading to a really ridiculous situation. 
and correct interpretation. It was an act of power, because church leaders possess enormous power when it comes to interpretation (cf. Malley, 2000). Dominees (and by implication their teachers, the professors) are considered to be experts in generating the meaning of a biblical text. Not only do they tell the congregations how to read the Bible but they can change opinions.

In their testimony, they renewed their faithfulness to their perception of the orthodox Reformed tradition: The Bible is the authoritative Word of God, sufficiently containing God's will and the doctrine of salvation. Scripture is the source and norm for the church, theology and Christian life. The Bible is not an unreliable document for faith and they reject the idea that it is a book containing human thought or human experience about God. In fact, they have a problem with the abuse of the Bible that authorises human prejudices and arguments. The Holy Spirit leads the faithful to understand the Bible correctly, to explain it in a true way, to apply it relevantly and to live it obediently.

The statement rejects an "abuse" of the Bible in authorising human prejudices and arguments, yet there is a glaring omission of the authors' own philosophical bias. How would one recognise any human prejudice or argument when any bias (ideological or philosophical) is not declared? Moreover, it looks as if the undeclared philosophical framework is simultaneously responsible for excesses against life, fellow human beings and environment. The view of Scripture is formulated in objectivist language and some of the issues the authors want to address emerge from the excesses of objectivism.

\subsection{An objectivist framework}

By objectivism is meant (cf. Snyman \& Vorster, 1999:53-55) the idea that knowledge exists independently of human perception. Perception is not influenced by personal feelings or opinions. A person can perceive reality without any preconceived ideas. Objectivity enables people to have objective truth, that is, a truth that can be grasped as something independent of human existence. It is a truth that exists outside the human mind and can be grasped by the mind on the condition that the mind has shed its prejudices or subjective feelings.

Subjectivity has no role, but the exclusion of the human perspective has led to serious abuses of people in the past. Apartheid is one recent example. The apartheid policy was ideologically driven and the effect it had on human beings was never taken into account. The same could be said of the attitude to the environment. In the living out of the human cultural task, nature as an object became exploited and polluted. It is 
only now that one asks about the effect of one's acts on nature. In objectivism effects are not inquired into. That would have introduced subjectivity into the scheme of things.

When people ask how apartheid could have evolved amidst the preaching of reconciliation, justice and peace, how it was possible that members of churches could have intentionally committed murders and sabotage, or how it happened that the sermons, liturgies or sacraments did not disturb the conscience of people (cf. The open letter, 1998:9 and Snyman, 1999b), the answer should be sought in our objectivist theoretical framework. 4

Without any need to take a human perspective into account, the prevailing apartheid ideology within which the text was read, enabled the reader of the Bible, or the hearer of a sermon, to follow the impulses of a perceived benign text which he or she was asked to imitate. The imitation of the text was perceived as a way to accomplish the will of God in one's life. There was no pressing need to look at the effects of one's reading, since the text was regarded as divine revelation, and therefore benign. Without any human thoughts or experiences about God to be taken into account, and with the Holy Spirit to lead the way, there was no possibility of recognising any ideology at all. One simply read the text that provided one with the will of God. Perception was immediate and judgment was steered by the Holy Spirit.

In the apartheid years, people could not act or read otherwise, since their view of Scripture acted as a protective sheath for the theological justification of apartheid in Afrikaner civil religion. The same may be happening again regarding the exclusion of women in the ministry. The view of Scripture embodied by the declaration provides no key to recognising any ideology or interpretive framework. Women are excluded from public office. The fact that men decide to exclude women, and the fact that this decision operates within a patriarchal set of rules, are not

4 In Snyman (1999b:404 ff) I discussed the problem of objectivism and orthodoxy. There I argued that apartheid's theological justification was heavily influenced by J.D. du Toit (Totius), an influential figure in the RCSA with an enormous following. To the argument that orthodoxy is not responsible for the theological justification of apartheid (cf. Jackson, 2001), I would say that the evidence found in Totius' writings indicates the contrary, unless he is not regarded as an orthodox theologian. In this context I mean by the term orthodoxy that emphasis is put on the Bible that separates it from any other book (sola Scriptura) as well as the exclusion of any human involvement, so that the Bible as Word of God can be rendered free from any mere human opinion. I think this understanding of "orthodoxy", which is related to the Calvinist tradition, fits Totius's views. 
recognised. The power behind the authoritative interpretation is masked and filled with prejudice.

\section{Afrikaner civil religion}

\subsection{State theology, religion and the Afrikaans churches}

Civil religion is a religious dimension of daily life that draws upon religion, political ideologies and common historical experiences of a group of persons in order to unify them (Christi \& Dawson, 1996:321). In apartheid civil religion, the Calvinist religious tradition provided the religious base for the upsurging nationalism of the 1930s and 1940s of a group of people who had suffered under British colonial rule since the previous century (cf. Louw, 1989:47). There was a close link between religion, state theology and the Afrikaans-speaking churches.

How close religious attitudes and nationalism came to each other, can be seen in the words of D.F. Malan, the dominee-turned-prime minister, after the National Party victory in 1948 (cf. Moodie, 1975:204):

Afrikaner history reveals a firm resolve and purposiveness which makes one feel that Afrikanerdom is not the work of men, but the creation of God ... Throughout our history, God's plan for our People is clear, we have a divine right to be because God created our People.

Malan's past as dominee and his job as prime minister made the connection between religion and politics less problematical.

Malan was not the first. The icon of Afrikanerdom, Paul Kruger, president of the former Zuid-Afrikaansche Republiek and member of the RCSA, found solace in Calvin's Institutes and applied his thinking on revelation and covenant directly to the situation of his political context. Michael Prior (1997:89) narrates the following:

According to Kruger, God chose his Volk in the Cape Colony and brought them out into the wilderness, and, having chastened them, made a covenant with them, and 'the enemies were defeated and the trekkers inhabited the land which God had given them in this rightful manner'. God had visited his Volk with British imperialism because they had not fulfilled their covenantal obligations in celebrating the renewal of the covenant for over 30 years.

To Kruger, the British onslaught on the republics was an attack of the devil against the church of the Lord. The British forces might have had the numbers (they outnumbered the Boer forces), but the Boers had a supreme commander in Jesus Christ! 


\subsection{Mimetic identification with the woes of Israel}

There is a strong mimetic identification between the fortunes of the Jewish people as described in the Old Testament and the woes of a group of people who called themselves "Afrikaners". The appeal of the Judeo-Christian model of salvation created a very particular bond between God and the Afrikaner. Their history was interpreted as if God showed particular interest in them by specially selecting the Afrikaner people as a racial and/or cultural (ethnic) group, with its own God-given language and its own divine destiny (Moodie, 1975:204). Afrikaner nationalism had a biblical-theological core.

The Bible had a central role in the Afrikaners' psyche. Biblical language infused political discourse (Prior, 1997:91). Between the Anglo-Boer War of 1899-1902 that left the Afrikaner destitute and powerless, and the climax of Afrikaner nationalism in 1948, the image of Israel as an elected people provided solace to a rejected group of people ill at ease with their political existence. Their situation was vulnerable and perceived to correspond to that of the Israelites. Survival could be only ensured by keeping God's commandments.

Without recognising their own ideology, biblical texts in Deuteronomy 4 and 7 (God institutes a division among nations) were read as if it was a law for the Afrikaner people themselves. The laws of Moses that commanded Israel not to mix with the Canaanites (Deut. 22:9-11) became divine law for the Afrikaner, imploring them not to mix with other population groups, especially blacks who became associated with the sons of Ham (cf. Hamerton-Kelly, 1993:169). If God separated the nations in this way, no one had the right to change it. The prohibition of mixing with indigenous people soon provided a theological basis for the Immorality Act that prohibited mixed marriages.

One of the main proponents of this concept was J.D. du Toit (Totius), a professor at the Theological School in Potchefstroom. He wrote (1977: 340) the following on Deuteronomy 22:9-11:

Firstly, what God united, no one may divide. This is the basis of our plea for unity among Afrikaners... Secondly, we may not unite what God has divided. The council of God is realised in pluriformity ... Consequently we do not want any equalisation or bastardisation.

There was a spontaneous yet naive mimesis between the Afrikaner and the Book of Deuteronomy in a romanticisation of Israel (cf. Deist, 1994). The Afrikaners' associative identification with ancient Israel empowered them to transfer some concepts of the Jewish laws to their own social order. 


\subsection{Perverted Calvinism}

Central to Afrikaner civil religion was Abraham Kuyper's ideal of a Christian national state where authority comes from God and governance is guided by a Calvinist Christianity. The Calvinist's role was to bring the whole of life under the canopy of God (cf. Prior, 1997:90; Kinghorn, 1986:58-62). But it was not a pure Calvinism that held sway. Bax (s.a.:28) talks of a perversion of Calvin, and Deist (1994:18) refers to a "Boer Calvinism", a mixture of Kuyper and Princeton Fundamentalism. The "perversion" and Fundamentalism shared the notion of commonsense realism. Whereas Kuyper provided the link between the Bible and political life, common-sense realism provided the manner in which that link would originate, namely from a plain sense of the Bible or a literal reading of the Scriptures. The human mind is not allowed to impose its categories on the text, as Scripture merely reveals the plain sense of things. The Bible is clear. Common-sense realism (rooted in objectivism; cf. J.N. Vorster, 1988) became, in the 1930s and 1940s, the most preferred intuition for rationality, as it enabled the leaders within Afrikaner civil religion to seize upon those doctrines that satisfied their social, economic and political needs (cf. Deist, 1994:19).

Common-sense realism, a reaction to the philosophy of ideas propounded by Locke and Hume, is a philosophical framework with which reality is observed as a primary entity. The reality of the real world of objects that is observed is regarded as factual. Objects are observed as objects that exist independently from one's perception or one's concept of them.

Has the RCSA changed its position considerably since J.D. du Toit's common-sense realist readings of the biblical text? The Reformation Day declaration critiqued in the previous section does not testify to a move away from common-sense realism and its concomitant objectivism. Neither does the article by J.C. Coetzee, B.J. de Klerk and L. Floor on "Die hermeneuse van die Skrif met die oog op hedendaagse kerkliketiese vraagstukke" (In die Skriflig, 1980(14):12-26). Moreover, as long as there are large residues of common-sense realism and objectivism in the RCSA's reading practices, one cannot expect them either to confess anything about apartheid or to allow women in the ministry. 


\section{A critique of the locus classicus of the current hermeneutics in the RCSA thinking}

\subsection{Philosophical presuppositions}

The article "Die hermeneuse van die Skrif met die oog op hedendaagse kerklik-etiese vraagstukke" had an enormous influence on the way the dominees within the RCSA were trained to read the Bible. From the very start one realises it is permeated by objectivism. In fact, as is the case with the declaration on the eve of 2000's Reformation Day, one feels that the confession regarding the Bible as Scripture is more an ode to objectivism's exclusion of subjectivity than an ode on the Bible. The definition of exegesis with which the article starts (Coetzee et al., 1980: 12), warns against the darker side of the art of explanation, which is linked to subjectivity, namely the ever-present temptation to be led by one's own thoughts and not by what is written in the text. The article locates exegesis within objective perception. The text is not read with preconceived ideas. Rather, what one sees on paper, is what is read.

However, the authors (Coetzee et al., 1980:13) acknowledge that the approach to the text is filled with presuppositions. An important presupposition to them is the nature of the Bible, of which there are only two choices: a human book or a divine book. I find it perturbing that despite the acknowledgement of presuppositions, no philosophical presuppositions are named, nor is their influence on the perceptions of the authors traced. What happens is that the antagonistic views are scrutinised for philosophical presuppositions in order to be labelled and discarded as evidence of human thoughts not being able to listen to the biblical text, as was the case in the hermeneutical shift taking place in the GKN in the Netherlands at that moment (Coetzee et al., 1980:14-15; cf. The GKN report on Scripture's authority, 1981). In contrast to the GKN's allusion to time-boundedness (tydsgebondenheid) the concept of tydsgerigtheid (directed to a particular time) is offered (Coetzee et al., 1980:17). The article (Coetzee et al., 1980:14) is correct in sensing a new philosophical approach to the Bible, but it is wrong to accuse the antagonists of using a philosophical concept of truth, since the article uses it too. It just fails to recognise it.

To have a starting point in philosophy quickly became a bone of contention between the GKN and her critics. Velema (1981:20) argues the following:

My conclusion is that the concept of truth as key for understanding the problem of Scriptures is philosophical in nature. A man like Calvin 
fought against this. He detested the dominance of philosophy in Scholasticism and called for Scripture to speak for itself. 5

But let us remind ourselves of the influence of Abraham Kuyper and the "Boer Calvinism" that sought to christianise society. You start with the Bible and not with philosophy.

In fact, philosophy was targeted to be "christianised". In the current debate about the role of women in church and society, the RCSA is reaping the fruits of the past's "christianisation" of philosophy. The Bible is put on a par with philosophy. The problem is that before one reads the Bible, one already has a philosophy which has established an epistemological framework with which the text is approached. The Bible does not speak without a human being who makes it speak. And the human being who makes the Bible speak, employs his or her presuppositions to make it speak. Those presuppositions are found in culture in general. That is where philosophy has its influence.

The Bible is read with the same presuppositions one uses to read other texts. The fact that the Bible is a religious book, would just add another presupposition and does not necessarily cancel others. It is unfortunate that the beam in one's own eye is not recognised. The article, so it seems, operates from an objectivistic framework, which was exactly the problem the GKN had in their own society.

\subsection{View of Scripture}

The mentioned article's basic point of departure is the following (Coetzee et al., 1980:15): the immediacy of the Bible as the universal and alwaysvalid Word of God. As in the declaration I discussed, immediacy of perception is important. God merely transfers his thoughts to the human being. Because the Bible is immediate, its antiquarian nature is not a problem, as it speaks directly into the modern world. Behind this premise is the common-sense belief in the possibility of mutual understanding. This is not the problem, as communication theory is based on this premise. It becomes a problem when it undergirds the notion of an intersubjective world, common to all. Such a notion is based on the assumption that the speaker in the Bible and the reader of the Bible share a perceptual field. The notion works well in oral communication when speaker and hearer are in each other's presence, but not when the

5 "Mijn conclusie is dan ook dat het waarheidsbegrip als sleutel voor het hele Schriftvraagstuk van filosofische aard is. Daartegen heeft man als Calvijn juist so gestreden. Hij heeft de heerschappij van die filosofie in de scholastiek gehekeld met een beroep op het spreken van de Schrift zelf." 
speaker is no longer present and the reader has to deal with the words on paper.

To overcome this problem (Coetzee et al., 1980:16), the Bible is declared clear (perspecuitas). To facilitate the immediacy of perception, the object of perception needs to be clear. It is argued that the author did not intend to mislead the reader. What has been written is there for everyone to see. The point is, I think, that the words written in the text exist really and independently of observation. Misreading or misunderstanding lies with the reader, and not with the text, which exists independently of the human mind. The text is not a fantasy in the mind, but an objective reality anyone can take note of.

\subsection{Tydsgerig / tydsgebonde}

With Coetzee, De Klerk and Floor's distinction of tydsgerig (directed to a particular time) and tydgebonde (time-bound), the article's main hypothesis is painted into a corner when the position of women is considered. The article (Coetzee et al., 1980:18-19) suggests that although certain aspects are connected to time (i.e. cultural historical background), the text's universal aspects should not be neglected. With the employment of human thoughts ruled out, I am not sure a reader has any chance of distinguishing between what is connected to time and what is more universal. The question of who and what decides what is valid and universal (or not), is not answered. The reference to a woman's headdress and silence in the gathering just obscures the matter. It refers to the libertinism of women in those times where their urge for freedom led them to enter the congregation and speak without a headdress. What is bound by time and what is more universal: the urge to be free or the lack of a headdress?

The fact that female members in the RCSA no longer wear headdresses, yet are prohibited from the ministry, suggests to me that the cultural practice of the headgear relates to the time-boundedness, whereas the false urge for freedom against which Paul is thought to aim his discourse, forms the universal principle. Why can patriarchal hierarchy also not be bound by time? Who decides what is bound by time or not? The readers and their ideologies? I have the impression that, despite any claims to the contrary, in the current discussions about women in church and society the Bible simply serves as a coat-hanger on which particular ideas regarding the social role of women are hung in order to promote, in the name of the Bible, a particular view (cf. also W.S. Vorster, 1984:211).

The immediacy of perception that underlies the basic premise of the Bible as the universal and always-valid Word of God undermines any 
distinction between being connected to time and(?) tied by time. In conjunction with the principle of Sacra Scriptura sui ipsius interpres on which the article (Coetzee et al., 1980:19) is based, a serious lack of historical awareness is created, as the contexts of the different books in the Bible are simply not brought into consideration. By historical awareness I understand the ability to distinguish between the past, present and future. It is the ability to recognise a difference in time and culture, a difference between past events and the context to which the past events refer. It takes into consideration the discontinuity between Bible readers and the world of the Bible (be it the world of text production or the story world). A lack of historical awareness is created by subsuming one's own history in the stories told in the Bible, as if your story and the Bible stories were one harmonious reality under God's rule.

Under such a supranaturalistic view of history no human contribution is needed. Worse still, with an objectified text on a pedestal any problem relating to the biblical text is simply attributed to the failure of human understanding, for example the "mistake" of allowing philosophical frameworks to play a role in the reading of the biblical text! There can be no understanding for what the reader brings with him or her to the text during the reading process, if the text's perception is perceived to be immediate.

\subsection{The myth of a literal reading}

Immediacy of perception results in a literal reading of the text. A literal reading (cf. Rommetveit, 1988) is based on a common-sense notion that the word in isolation has a general basic down-to-earth meaning which is context-free and which originates in a pervasive objective world. But literal understanding is a myth. In an oral situation, meaning is established by an interaction between the speaker and the hearer during which mutual interest and a shared perceptual field are established. With writing, the picture changes, as the reader cannot question the author on the social embeddedness of the words used in the text. Remoteness in terms of time and space, and the anonymity of most biblical authors, make it very difficult to establish any sense of mutual interest or shared perceptual field. The taken-for-granted background conditions which one sees more readily in face-to-face communication, or the social embeddedness of the discourse, cannot be fully taken into account. It has to be constructed from sources other than the author, so that there is always a residue of indeterminacy (cf. Snyman, 1998:347). But even in an oral situation, the reality of social and contextual features (i.e. background assumptions) makes the process rather unstable. You can never tell if you really understand the other. 
The assumption of a shared perceptual field embodies an expectation of relevance. Such an expectation is assumed under the rubric "scope of the Bible" which defines what the reader should expect to find in his or her reading of the text. The question is not whether the text has anything to do with the reader, but how one applies the text to one's life. From the very beginning the biblical text is accepted as a benign text. The expectation that God may speak through the text gives the text an epistemological privilege by becoming a norm for life which must be imitated at all costs. However, the problem is that the text is not always benign, so that imitation runs into problems. The problem of imitation will now be discussed.

\section{Mimesis: "example is better than precept"}

\subsection{Domestic ideals and ascetism}

Imitation is the way we learn, behave, and act. Mimesis is based on identification, especially when it is admirative, associative, or even sympathetic (cf. Jauß, 1982:252 f.f.). This viewpoint can be traced back to Plato's doctrine of ideas where the artist is thought of as only capable of imitating an idea, and never being able to represent that idea in full. That is why popular magazines flourish. They provide readers with lots of examples to imitate. Just page through rooi rose, Sarie or Finesse. You will find a lot of beautiful people, celebrities oozing success or ordinary readers relating how they overcame obstacles. They all look their best. There is always a fashion section on how to clothe oneself stunningly, a health section with advice on how to keep the body trim and a presentation of the latest cosmetics on the market.

The presentation of beauty and success has a reason. They are the outcome of the influence of two religious beliefs influencing womanhood in the Judeo-Christian tradition:

- Women are closer to their bodies than men (except when you read Men's Health!)

- Perfection is achieved by the subjugation of the flesh (Lelwica, 1998§5).

These two beliefs, which give these magazines a quasi-religious function, are recycled in two visions of womanhood:

- The domestic ideal, which is seen in images of motherhood and marriage. 
- The ideals of asceticism which can be observed in visions of female independence, career success, idealised beauty and physical discipline (cf. Lelwica, 1998§11).

In Early Christianity women were condemned to the very flesh they were supposed to transcend in order to be saved. Salvation was achieved by fulfilling their physical destiny in becoming good mothers and dutiful wives, or by becoming ascetic in subjugating the female flesh with fasting and virginity. I think the depiction of the woman's primary role in caring for the body in the form of domestic service (Eve's legacy, renewed by Paul) is the main reason why women in the RCSA are not allowed into the ministry. RCSA women are forced to imitate the biblical images of women in the Bible: her susceptibility to bodily cravings (she took the first bite) condemned her to a proximity to her body by bearing children and pleasing her husband sexually (cf. 1 Tim. 2:9-15). Her condemnation to the flesh makes her unsuitable to speak in spiritual matters. The body is an obstacle to the pursuit of spiritual values. In terms of Paul's idea that the body is inferior to the soul and an impediment to Christian perfection, the exclusion of women in spiritual affairs is just the logical conclusion of the subjection of the body.

In terms of the hermeneutics spelt out in the previous section, the Bible receives credibility as the "Word of God" when it succeeds in embodying the norms of current society. One of the ways its norms evolve into modern society is by imitating the values embedded in the text of a character who is worth following. The biblical figure gives the reader a grip on how to handle life.

\subsection{Human imitation}

The only problem with the biblical models is that they are deemed so perfect that human imitation would never achieve the purity of the biblical model itself. In this way a particular relationship of power is established. One such model is Paul, who actually demands to be imitated (1 Thess. $1: 6$; 2:14; Phil. 3:17; 1 Cor. 4:16, 11:1). Elizabeth Castelli (1991:6) has indicated that Paul's exhortation is not a "benign call to emulate a laudable ethical model" (Castelli, 1991:16). She sees in it "a far more profoundly embedded understanding of the privileged position of the apostle to construct the early communities within a hierarchical 'economy of sameness'" and an erasure of difference (Castelli, 1991:117):

Participating positively in the mimetic relationship with Paul, the early communities are to be rewarded with salvation. Resisting the mimetic relationship, by contrast, has dire consequences. 
Paul's invocation of mimesis indicts the very notion of difference, and thereby constructs the nature of early Christian social relationship: Christians are Christians insofar as they strive for the privileged goal of sameness. Christians distinguish themselves from those who are not Christians, who are not saved, precisely in this drive for sameness. Difference has only negative connotations in this mimetic economy.

Paul's use of imitation corresponds to its use in the Greco-Roman context (cf. Castelli, 1991:16):

- Mimesis creates a hierarchical relationship where the copy is but a derivation from the model, which has a privileged status to which the copy never can aspire. Thus, I would say, Paul regards himself as a copy of Jesus (1 Cor. 11:1), and his followers must be a copy of him (Paul; 1 Cor. 4:16).

- Mimesis prefers sameness to difference. Unity and harmony are associated with sameness, whereas difference is associated with discord, diffusion and disorder. In my opinion, the implication is that a rejection of the call to imitate Paul constitutes difference, so that those who do not imitate him, cannot claim to be followers of this new movement (cf. Phil. 3:17).

But Paul, privileged as he was, could not have talked from the perspective of a tabula rasa. He shared his society's frame of reference regarding philosophy and social organisation. Symbolic production, since the early origin of Israel, until very recently, had been controlled by men. What does this mean? In a text written by men a female character will be a male construct, reflecting androcentric ideas about women and serving androcentric interests (cf. Exum, 1999:150). Women were inscribed as "the other" which defined, as well as threatened, the boundaries of the patriarchal order. I doubt that there was malicious intent. That was how society functioned. Women were the objects of male possession and control.

\subsection{The female body and Israelite social order}

The body is the primary locus for the articulation of larger complexes of meaning which constitute a cultural system, says Eilberg-Schwartz (1991:178). Regulations about the body, such as those regarding blood and semen, tie abstract themes of social concern to everyday life. In the Old Testament, the body was closely linked to the relationship between God and Israel. For covenant, righteousness and wholeness, the male penis with circumcision became the locus of meaning, whereas sin, indecency and death were encoded in the pollution codes regarding female menstrual blood (cf. Eilberg-Schwartz, 1991:181, Keefe, 1999§6). 
The gender of blood is a symbol of different kinds of social relationships. Perceptions about the body in general, linked to a socio-cultural view of female bodiliness, could very well have been the reason why Paul assigns women to a particular social relationship in the congregation by asserting that she should cover her head and be silent. But does this constitute divine validation of patriarchal control over women in churches? Apparently yes, if one takes only Paul's closeness to Christ in mind and recalls the legacy of Eve (as perceived though patriarchal eyes!).

The biblical text gives one a picture of women as seen through the eyes of Judeo-Christian culture, where male dominance in the public sphere is embedded. The social order's perceptions of women seep through the texts we have inherited. But these texts do not tell the whole story. The picture they construct may not necessarily be an imitation of the reality of Israelite life or that of early Christianity. In this respect, Phyllis Bird (1999) is very adamant that women are not denigrated sexual objects, but actors in their own right. She argues that the historiography of Israelite religion is skewed in its lack of attention to the role of women in the Israelite cult (Bird, 1999:4), due to the lack of biblical and extra-biblical sources. There are at best isolated fragments, making any construction tentative and qualified. The presence of female figurines on domestic altars and the presence of the asherim trees suggest a female religious symbolism (cf. Keefe, 1999§14).

Israelite social order shared in a sexual division of labour which was pronounced in pre-industrial agricultural societies (Bird, 1999:5). This division of labour caused women to be restricted to the domestic sphere, whereas men mainly acted within the public sphere, where women had marginal roles. For women the religious activities centred in the domestic realm: local shrines, saints and spirits, home rituals in the company of other women, the making and paying of vows, life-cycle rites, attest to women's spiritual and emotional needs, which are not addressed by the central sanctuary, great pilgrimages or assemblies (Bird, 1999:6).

Although women had autonomy in the domestic sphere, the power of production was within the male-dominated public sphere, which would not necessarily look favourably on what happened in the domestic sphere. Women were not deemed to be central to the cult in the public sphere. They were restricted from the governing institutions' inner circle - elder and priesthood - but were allowed into the outer circle, where they indeed shared many of the same rights and duties as men (Bird, 1999:17). This is imitated by the RCSA in her denial of female participation in any public office (elder, deacon or dominee). 


\section{Can women be told to be like men?}

With the Bible as God's word in which he reveals himself to humankind, and with that revelation regarded as a norm for life on earth, chances are very good that the entire Bible is conceived of as a benign text. "Benevolence" is inscribed into the text from the very start. In other words, the text means well, even if it seems discriminatory, as it concerns God's will where everything is for the best. People and values can be copied or imitated.

If it is true that the Bible was to a large extent written from a male perspective, the call to imitate values and characters results in the situation where women, so the argument goes (cf. Tolbert, 1990:17), are asked to become like men. Women are posed with a dilemma, since difference, according to Paul, excludes people from the circle of Christians. Paul did not intentionally or maliciously impose a male system of values. Being the public transcript, maleness was simply accepted as the norm. Feminist interpretation and its accusation of the emasculation of women by men, should make one sensitive to the gender bias of the biblical texts. In a society striving for equality, this means that "humanity" and "masculinity" are not to be equated. The ideology of equality necessarily becomes one of the presuppositions with which the text is being read. Then it is a shock to discover the masculinity of Jesus as Clines (1998) recently did. 6

A sensitivity to the cultural norms embedded in the biblical text is called for, especially if the male is presented as normal and universal and the female as the marginal or the deviant. I think that such a sensitivity is already in place. Each Sunday, when the dominee reads the last commandment ("You shall not covet your neighbour's house. You shall not covet your neighbour's wife, or his manservant or maidservant ...") women are asked to identify with the male point of view. If that commandment is taken at face value, it means that women are not allowed any lesbian relationship with an equal (the neighbour's wife) or a subordinate (the neighbour's maidservant) or a heterosexual relationship with a subordinate (the neighbour's male servant). But a relationship with the neighbour himself is quite in order ...! I doubt that the commandment

6 Clines (1998) mapped the masculinity of his character in the Gospels as follows: he is strong, violent, a powerful and persuasive speaker, a male bonder, womanless and a binary thinker: "[H]e is out to win, on a daily basis and as a life goal; and win he does, according to the Gospel story. He is a man's man, by any standard, ancient and modern" (Clines, 1998:374). To Clines, his masculinity does not make him bad, nor does he find approval in some aspects, for example his violence or domineering aspects in his behaviour or speech. But he finds a resonance in his binary thinking. 
is taken in this way. It is transformed to include any illegitimate heterosexual relationship.

Tolbert (1990:19) says that reading a text as an androcentric text does not mean the text is thrown away. She talks of a negative hermeneutic that lays bare the patriarchal ideology, and a positive hermeneutic that recuperates what she calls that utopian moment, those aspects that touch authentic human desires and experiences. However, the question is: Who or what determines the utopian moment of the text? Or in Coetzee, De Klerk and Floor's terms, who or what decides what is related to or tied by time and what is universal and generally valid?

The orthodox tradition suggests Scripture itself does so, but I tend to agree with Tolbert (1990:16), who argues that such a claim merely masks the institutional biases of authorised interpretations. I would argue that the reader decides those questions. The religious weight posed by the text as "Word of God" creates within the reader a responsibility to do justice to the text. That responsibility is twofold and formulated by Elizabeth Schüssler-Fiorenza (1988:14-15) as an ethics of historical reading and an ethics of accountability. An ethics of historical reading seeks to give the text its due by asserting its original meanings over and against later dogmatic usurpations. An ethics of accountability relates to the choice of the theoretical interpretive model as well as the ethical consequences of the text and its meanings.

The reason I find Schüssler-Fiorenza's proposal attractive, is that it acknowledges that the reader plays a significant role in the reading process, and that the reading is not unbridled. There is a responsibility towards the text as well as to the effects of the reading of the text, to those who will bear the marks of that reading. In this manner, readers can become sensitive to an ethical scrutiny of the text (cf. Carroll, 1993: 88) and its legacy of support for the colonising activities by theological and exegetical assertions, from within religious and academic circles (cf. Prior, 1997:291). The Bible as a legitimating document for colonising ventures was used against groups of people who had no corresponding authority. It is a striking example of religious and political imperialism (cf. Prior, 1997:290). The use of the Bible as an androcentric text to exclude women from public office within the church would repeat this kind of imperialism.

\section{Bibliography}

AMADOR, J. 1999. Academic constraints in rhetorical criticisms of the New Testament. An introduction to a rhetoric of power. Sheffield : Sheffield Academic Press. (Journal for the Study of the New Testament Supplement Series, vol. 174.) 
BAKHTIN, M. 1984. Theory and History of Literature. Vol. 8: Problems of Dostoevsky's poetics. Introduction by Wayne C. Booth. C. Emerson, trans. Minneapolis : University of Minnesota.

BAX, D.S. S.a. A different gospel. A critique of the theology behind apartheid. Johannesburg : The Presbyterian Church of Southern Africa.

BIRD, P. 1999. The place of women in the Israelite cultus. (In Bach, A., ed. Women in the Hebrew Bible. A reader. New York : Routledge. p. 3-20.)

CARROLL, R.P. 1993. The Hebrew Bible as literature - a misprision? Studia Theologica, 47:77-90.

CASTELLI, E.A. 1991. Imitating Paul. A discourse of power. Literary currents in biblical interpretation. Louisville, Kentucky : Westminster/John Knox.

CHRISTI, M., \& DAWSON, D.L. 1996. Civil religion in comparative perspective: Chile under Pinochet (1973-1989). Social Compass, 43(3):319-38.

CLINES, D.J.A 1998. Ecce vir, or, gendering the Son of Man. (In Exum, J.C. \& Moore, S.D., eds. Biblical Studies/Cultural Studies. The third Sheffield colloquium. Sheffield : Sheffield Academic Press. p. 352-375.)

COETZEE, J.C., DE KLERK, B.J., \& FLOOR, L. 1980. Die hermeneuse van die Skrif met die oog op hedendaagse kerklik-etiese vraagstukke. In die Skriflig, 14(54):12-26.

DE KLERK, B. et al. 2000. Teoloë gee op Hervormingsdag perspektief op Skrif. Beeld : 15, Okt. 31.

DEIST, F.E. 1994. The dangers of Deuteronomy. A page from the reception history of the book. (In Martinez, F.G., Hilhorst, A., Van Ruiten, J.T. \& Van der Woude, A.S., eds. Studies in Deuteronomy. In honour of C.J. Labuschagne on the occasion of his 65th birthday. Leiden : Brill. p. 13-30.)

DU TOIT, J.D. 1977. Die staat, maatskappy, taal en kultuur. Versamelde Werke. Deel 7. Kaapstad : Tafelberg.

EILBERG-SCHWARTZ, H. 1991. The savage in Judaism. An anthropology of Israelite religion and ancient Judaism. Bloomington : Indiana University Press.

EXUM, C. 1999. Who's afraid of "the endangered ancestress"? (In Bach, A., ed. Women in the Hebrew Bible. A reader. New York : Routledge. p.141-56.)

GEREFORMEERDE KERKE IN SUID-AFRIKA. 1988. Handelinge van die drie en veertigste Nasionale Sinode te Potchefstroom op 5 Januarie en volgende dae. Potchefstroom : Herald.

GEREFORMEERDE KERKE IN SUID-AFRIKA. 1994. Handelinge van die vyf en veertigste Nasionale Sinode te Potchefstroom op 3 Januarie en volgende dae. Potchefstroom : Herald.

GEREFORMEERDE KERKE IN SUID-AFRIKA. 2000. Handelinge van die sewe en veertigste Nasionale Sinode te Potchefstroom op 10 Januarie en volgende dae. Pretoria : V\&R Drukkery.

GKN Report. 1981. God met ons ... over de aard van het Schriftgezag ... Special Kerkinformatie, vol. 113. Utrecht : Tijl-Libertas.

GKSA ( = RCSA) see GEREFORMEERDE KERKE IN SUID-AFRIKA

HAMERTON-KELLY, R. 1993. Biblical justification of apartheid in Afrikaner civil religion. (In Keulman, K., ed. Critical moments in religious history. Macon : Mercer University Press. p. 161-72.)

JACKSON, N. 2000a. GKSA sê weer nee vir vroue in ampte. "Slotsom berus op getuienis uit Bybel" "Nie finale besluit, kan verander word". Beeld : 12, Jan. 19.

JACKSON, N. 2000b. Vroue sélfs dan onwelkom. Beeld: 6, Jan. 21. 
JACKSON, N. 2000c. GKSA sê ja vir "nuwe studie" oor rol van vrou in kerk. Beeld: 9, Jan. 20.

JACKSON, N. 2000d. Beswaarskrifte slaag soms om kerkorde-besluit te laat verander. Beeld : 13, Jan. 28.

JACKSON, N. 2001. "SA het behoefte om Bybel nuut uit te lê". Beeld : 5, Mei 3.

JAUß, H. 1982. Ästhetische Erfahrung und Literarische Hermeneutik. Frankfurt am Main : Suhrkamp.

KEEFE, A.A. 1999. Stepping in/stepping out: A conversation between ideological and social scientific feminist approaches to the Bible. Journal of Religion and Society (electronic), $1: \S 1-\S 22$.

KINGHORN, J. 1986. Die teologie van apartheid: vormende faktore. (In Kinghorn, J., red. Die NG Kerk en apartheid. Johannesburg : Macmillan. p. 47-69.)

LANSINK, A. 2000. "Speaking truth to power". Mail \& Guardian : 47, Dec. 1-7.

LELWICA.M. 1998. Fulfilling femininity and transcending the flesh: Traditional religious beliefs and gender ideals in popular women's magazines. Journal of Religion and Society (electronic), 1:§1-§31.

LOADER, J.A. 1979. Ortodokse fundamentalisme en die gebruik van die Ou Testament in Suid-Afrika. Hervormde Teologiese Studies, 35:101-118.

LOADER, J.A. 1996. 'n Hervormde tradisie as heelmiddel. Hervormde Teologiese Studies, 52(4):566-589.

LOUW, D.J. 1989. Omnipotence (force) or vulnerability (defencelessness)? The significance of a theological interpretation of the category of power on an ethic of conflict management. Scriptura, 18:41-58.

MALLEY, B.E. 2000. Rethinking Bible interpretation, 18 October. Paper circulated via an Internet discussion group.

MOODIE, T.D. 1975. The rise of Afrikanerdom. Power, apartheid, and the Afrikaner civil religion. Berkeley : University of California Press.

PRIOR, M. 1997. The Bible and colonialism. A moral critique. Sheffield : Sheffield Academic Press.

ROMMETVEIT, R. 1988. On literacy and the myth of literal meaning. (In Säljö, R., ed. The written word. Studies in literate thought and action. Berlin : Springer. p. 13-40.)

SAID, E. 1994. Representations of an intellectual. The 1993 Reith Lecture series. London : Vintage.

SCHÜSSLER-FIORENZA, E. 1988. The ethics of biblical interpretation. Decentering biblical scholarship. Journal of Biblical Literature, 107:3-17.

SNYMAN, G.F. 1997a. Stel rassevooroordele van Totius aan die kaak. Beeld : 8, Jan. 24.

SNYMAN, G.F. 1997b. Dit is tyd dat GKSA besef kritiese teologie het 'n rol. Beeld : 8, Okt. 10.

SNYMAN, G.F. 1998. The religious performer as $s(m)$ oothsayer. Scriptura, 67(4): 343-62.

SNYMAN, G.F. 1999a. "Ilahle elinothuthu?" The lay reader and/or the critical reader some remarks on africanisation. Religion \& Theology, 6(2):140-67.

SNYMAN, G.F. 1999b. "Will it happen again?" Reflections on reconciliation and structural contraception. Religion \& Theology, 6(3):379-410.

SNYMAN, G.F. 2001. "Who am I?" Some thoughts on fabricating the body in postcolonial/post-apartheid South Africa. Alternation, 8(1):188-218.

SNYMAN, G.F. \& VORSTER, J.N. 1999. Hermeneutics: Fundamentalism. Tutorial Letter 102/1999. Pretoria : University of South Africa. 
THE OPEN LETTER. 1998. An open letter to pastors of all churches in South Africa. (In Du Toit, C., ed. Confession and reconciliation. A challenge to the churches in South Africa. Pretoria : Unisa. p. 8-10.)

TOLBERT, M.A. 1990. Protestant feminists and the Bible. On the horns of a dilemma. (In Bach, A., ed. The pleasure of her text. Feminist readings of biblical and historical texts. Philadelphia : Trinity Press. p. 5-24.)

VAN WYK, J.H. 1997. Nasionalistiese politiek ook van liberale teologie. Beeld : 10, Okt. 20.

VELEMA, W.H. 1981. Het rapport "God met ons ... Over de aard van het Schriftgezag". In die Skriflig, 15(60):4-23.

VORSTER, J.N. 1988. The use of Scripture in fundamentalism. (In Mouton, J., Van Aarde, A.G. \& Vorster, W.S., eds. Paradigms and progress in theology. HRSC Studies in Research Methodology. Vol 5. Pretoria : Human Sciences Research Council. p. 55-75.)

VORSTER, W.S. 1984. The use of Scripture and the NG Kerk: a shift in paradigm or of values? (In Hofmeyr, J.A., ed. New faces of Africa. Essays in honour of Ben Marais. Pretoria : Unisa. p. 204-09.)

VROOM, H.M. 1993a. Scripture read and interpreted: The development of the doctrine of Scripture and hermeneutics in Gereformeerde theology in the Netherlands. Calvin Theological Journal, 28:352-71.

VROOM, H.M. 1993b. De veranderde lezing van die Bijbel. Gereformeerde Theologische Tijdschrift, 93:88-102.

\section{Key concepts:}

Afrikaner civil religion

ethics of reading

Gereformeerde Kerke in South Africa

hermeneutics

women - position of

\section{Kernwoorde:}

Afrikaner burgerlike godsdiens

etiek van lees

Gereformeerde Kerke in Suid-Afrika

hermeneutiek

vroue - posisie van 